\title{
THE SCHENGEN AREA - THE CHALLENGES OF ITS EXISTENCE AND THE NEED FOR REFORM
}

\author{
Līga Budeviča', Aija Čerpinska², Daina Znotiṇa ${ }^{3}$ \\ ${ }^{1}$ Senior inspector of Pededze Border Surveillance Unit of Vilaka Board of the State \\ Border Guard, e-mail: Liga.Budevica@rs.gov.lv, Latvia \\ ${ }^{2}$ Mg.soc.sc., Lecturer at Rezekne Academy of Technologies, e-mail: Aija.Cerpinska@rta.lv, \\ Rēzekne, Latvia \\ ${ }^{3}$ Mg.soc.sc., Lecturer at Rezekne Academy of Technologies, e-mail: Daina.Znotina@rta.lv, \\ Rēzekne, Latvia
}

\begin{abstract}
The Schengen area is a unique structure and one of the European Union's greatest achievements allowing people to move freely within its borders. However, the factors such as the refugee crisis and the influx of asylum seekers into Europe have led several Member States to reintroduce border controls at their internal borders. The aim of the research is to explore the Schengen area, the challenges of its existence and the need for reform. In order to implement the aim of the research, the authors have determined the following tasks of the research: 1) to explore and analyse the Schengen area and the reforms taking place in it; 2) to explore the challenges of the existence of the Schengen area; 3) based on the results obtained in the research, to draw conclusions and develop proposals. The study summarizes the reforms implemented and planned in the Schengen area, evaluates the existing challenges and relevance of the reforms to overcome them. As a result of the study, the authors conclude that it is necessary to ensure the Member States adopt measures to restore the proper functioning of the Schengen area and do not request extension of the reintroduction of the border control at the internal borders.
\end{abstract}

Keywords: border control, challenges, cooperation, reforms, Schengen area.

\section{Introduction}

Everyone who needs to move from home country to another is pleased to use possibility to travel freely. We also want everything to be comfortable and simple when travelling. In the past, the heads of the countries have made the travelling easier by creating the Schengen area. The area without internal borders - the Schengen - was set up at the intergovernmental level by the Member States wishing to abolish the internal border controls (European Commission, 2010).

The Schengen area is currently at the crossroad and decisive, strong, and joint action is needed to fully restore the benefits and guarantees it brings to the people. Fundamentally, there is also a need for a mutual trust, cooperation, and solidarity between the Member States, while not allowing political negotiations aimed at weakening and calling into question the benefits of the Schengen area.

The aim of the research is to explore the Schengen area, the challenges of its existence and the need for reform. In order to implement the aim of 
the research, the authors have determined the following tasks of the research: 1) to explore and analyse the Schengen area and the reforms taking place in it; 2) to explore the challenges of the existence of the Schengen area; 3 ) based on the results obtained in the research, to draw conclusions and develop proposals.

Hypothesis: The reforms taking place in the Schengen area ensure its existence.

Research methods: monographic, or descriptive method; logically constructive method; special literature and internet resources research method; comparative method; graphic method; quantitative research method; method of analysis and synthesis.

Research period: historical period, 2014 - 2019 (first 10 months).

Novelty of the research: the study, in the summarised way, analyses the reforms implemented and planned in the Schengen area, evaluates the existing challenges and assesses the aptness of the reforms in overcoming them.

Summarizing the research results, it can be concluded that the main value of the Schengen area is the possibility of free movement. However, the possibility of free movement is also viewed negatively, as it poses a threat to overall security. As the analysis in the study shows, the future challenges and necessary reforms for the Schengen area depend on the mutual cooperation and the desire to maintain an area without the internal border controls that ensure security. There must be global solutions to the current problems and future challenges. As the Schengen area consists of 26 Member States, the political views of each country also differ on various issues, which also depend on the country's geographical location, economic growth, and technical capabilities.

\section{Research results and discussion}

In 1985, no one was convinced that the union of free borders would have a future (Lipsnis, 2015). It is now possible to move freely to any country, and we can thank the EU legal framework and the Schengen agreement approved by the Member States for this (Štibe, 2019).

History shows that the Schengen area had faced various threats and challenges since its inception. Nonetheless, it continues to exist, as certain measures are being implemented to adapt the Schengen area to the current requirements and the constant change.

Since 2015, when the Schengen area encountered the mass migration flows and the secondary migration movement, various reforms have been envisaged and implemented to restore the proper functioning of the Schengen area. The measures to strengthen the Schengen area were 
implemented both at the external borders and within the area, as shown in Figure 1.

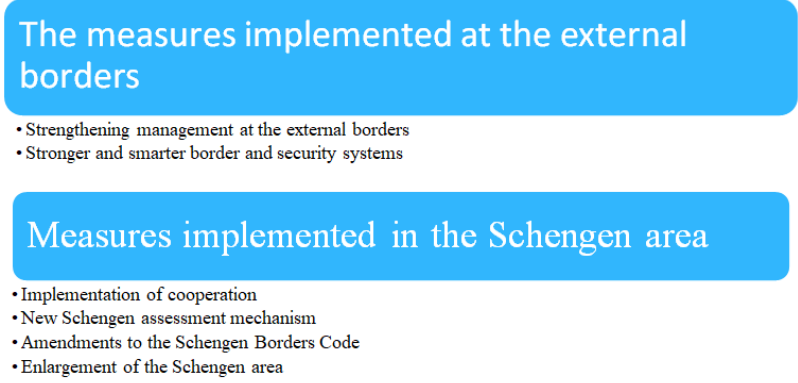

\section{Figure 1. The measures implemented in the Schengen area and at the external borders in 2015-2019 (created by the authors)}

In response to the challenges of the Schengen area existence, the reforms are being implemented both within the area and at its external borders. The reforms implemented so far show that they improve the functionality of the Schengen area and provide the necessary security measures.

A set of laws has been developed to ensure the proper functioning of the Schengen area; the Schengen assessment mechanism is used to monitor the application of the Schengen acquis and make recommendations on any shortcomings, however, it does not provide for the sanctions if the countries do not address the shortcomings.

In 2016, the existing European Agency for the Management of Operational Cooperation at the External Borders of the Member States of the European Union was strengthened renaming it into the European Border and Coast Guard Agency (FRONTEX) (On the European Border and Coast Guard Agency, amending the Regulation of the European Parliament and the Council (EU)), as well the European Border and Coast Guard composed of FRONTEX and the Member States' authorities responsible for border management, including border guards, insofar as it carries out border control tasks, was established (On the European Border and Coast Guard, amending Article 3 of the Regulation of the European Parliament and the Council). The strengthening of the European Border and Coast Guard Agency, FRONTEX, is linked to the need to continue to ensure the functioning of the "real Schengen" - the free movement of persons across 
the EU borders. On 4 December 2019, the new FRONTEX Regulation (On the European Border and Coast Guard, repealing the Regulations (EU)) entered into force, aiming to further enhance the overall level of security in the EU by managing the EU's external borders more effectively and enhancing the return of the persons without the legal base to reside in the EU, based on a more efficient exchange of information between the Member States, the EU agencies, and the third countries.

Two new large-scale information systems will also be introduced: the Entry/Exit System (EES) and the EU Travel Information and Authorization System (ETIAS). The aim of the EES is to modernize the management of the external borders by improving the quality and efficiency of checks and the detection of forgery of documents and identities. The system will apply to all third-country nationals who are allowed a short stay in the Schengen area at the moment they cross the Europe's external borders (European Parliament Office in Latvia, 2019).

As the Schengen area expands to include more countries, the Member States face an increasing threat as the area of control increases. The EU and the Member States can only secure a stronger Schengen area if they are united and work together. Croatia has taken steps to ensure that the necessary conditions are met. When it becomes a full member of the Schengen, it will contribute to the further strengthening of the Schengen area and ensure better protection of the EU's external borders (European Commission, 2019).

Currently, the Schengen area is characterized by three types of border walls: "Physical walls", "Mental walls", and "Virtual walls". "Mental walls" means criminalizing and securitizing the movement of people, especially refugees and migrants. "Physical walls" focus on land walls, fences, and maritime walls (Ruiz, 2018). We shall not forget the "virtual walls" - the border control systems aiming to stop people from entering the Schengen area and to control the movement of people (Akkerman, 2019). Each of these walls has its own function in providing security, but they could also be violated.

Global threats of terrorism and illegal immigration, climate overheating, energy dependence are some of the major challenges (Šulca, 2011). The Schengen area has already experienced a boom of terrorism and a crisis of the illegal immigration, and this threat has jeopardized its very essence - the right of free movement.

Analysing the challenges and assessing the possibilities of the Schengen area to overcome them and preserve its core value - the freedom of movement, the authors have created Figure 2 illustrating the successful implementation of the ideas. 


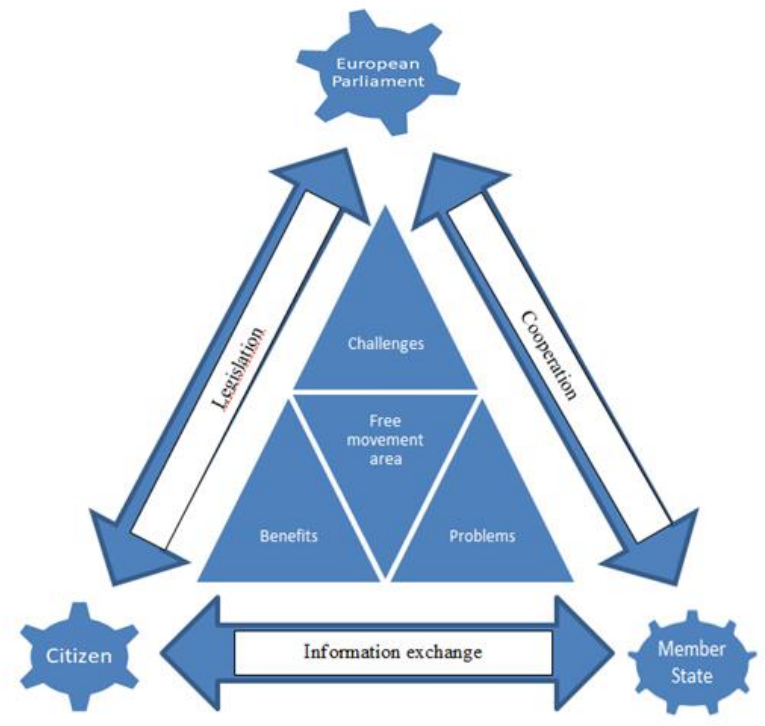

Figure 2. Implementation scheme for the Schengen area existence (created by the authors)

Looking at Figure 2, it can be seen that overcoming the challenges of the Schengen area is a joint effort involving citizens, the Member States, and the European Parliament. Cooperation, information exchange, and appropriate legislation are necessary for this mechanism to work. If at least one element of this scheme is missing, overcoming the challenges will be hindered. This means that the continuation of the Schengen area requires desire and joint work.

The main challenges facing the Schengen area are illegal migration, terrorism, and human trafficking, which are developing as a result of free movement and insufficient protection of the external borders. The interests of the countries depend mainly on their geographical location and, partially, on their political position.

Today, migration is facilitated by the new communication technologies and the information exchange in the social networks (Šnore, 2016), as people communicate more easily and quickly receive the newest and up-todate information about ongoing processes far from their home country.

One of the biggest challenges is and will be the integration of the thirdcountry immigrants and the Muslim community, which will necessitate the protection of the Western culture and the rights of Europeans (Kristovskis, 
2008). It is not possible to stop migration completely, just in solidarity with all Member States to take part in the reception of the refugees. Their free movement to another country within the Schengen area due to the better living conditions is problematic. This freedom of movement of the refugees destroys the balance in the Member States of the European Union, because, despite the fact that the refugee status is granted in each Member State separately, the physical stay of the refugees takes place in another, more attractive country, which places greater burden on that country. A common solution within the European Union is needed to ensure that the refugees have the same social and other guarantees in each country, i.e. to ensure that in each Member State a refugee could claim the same range of social and other guarantees, no more and no less than in other European Union country. The current system could likely to be improved with various types of benefits and job offers for the refugees (Gelpers, 2019).

The citizens' response by reporting an unknown suspicious person to the authorities is important in identifying illegal immigrants, as immigrants cannot hide for long. In response to the risk of illegal immigration, the previously analysed reforms of the Schengen area, such as the EES and ETIAS, are implemented, nevertheless, the current solution is to strengthen FRONTEX and deploy experts both at the EU's external borders and in the third countries.

Terrorism, which is considered to be one of the main challenges facing the humanity, is one of the most debated issues today not only in the Schengen area but also worldwide. Terrorist attacks in the Schengen area and elsewhere are a reminder that the fight against terrorism and the prevention of radicalization remain a priority for the European Union and its citizens. Domestic terrorists operating in networks, terrorists acting alone, and foreign fighters terrorists returning to their countries (European Commission, 2019).

The greatest threat to the Europe's internal security is posed by the individuals who have already gained combat experience and after returning to the home countries are ready to spread extremist ideas and apply their experience. The analysis of the terrorism trends suggests that long stay in the terrorist regions may encourage the individuals to get attached to a radical interpretation of Islam or even to establish contacts with the members of the terrorist groups there (Voins, 2015).

In the Schengen area, the biggest terrorism threat is posed by the Islamic terrorists (Lorencs, 2018). Today we live in a digital age, therefore, dealing with the online content related to terrorism remains a major challenge in preventing radicalisation. Reports by the Member States remain an important component of the response. The speed at which the companies respond to the reports varies widely - from less than an hour to 
several days, so the speed of the response needs to be further improved to properly comply with the legislative proposal adopted by the Commission in 2019 to remove content related to terrorism within one hour after receiving a report (European Commission, 2019). At present, all the main lines of the action against modern terrorism on the part of the international community and individual countries can be divided into three major sections, which are closely interlinked and cannot be implemented individually. One section is to prevent the creation of an environment conducive to the spread of terrorism through the adoption of new legislation, increased control of the financial flows, public education and other preventive measures. The second section is preparation of the special forces, the provision of technical means, everything necessary for responding to a crisis that has already taken place or is actually threatening. The third section is the follow-up measures to the terrorist attacks that have taken place: victim support, investigation of the consequences. A separate section in the fight against terrorism is the process of investigating the event: identifying, detention, and prosecuting the perpetrators (Voins, 2015).

The reforms in the Schengen area have also been implemented to combat the terrorism. For example, the revised mandate of the European Border and Coast Guard makes it possible to contribute more effectively to the fight against terrorism and to ensure greater coherence between internal and external security action. The exchange of information remains an extremely important element of the ongoing efforts to address the return of the foreign fighter terrorists to their home countries and to take wider counter-terrorism activities (Council of the European Union, 2017).

Human trafficking is considered the second most lucrative criminal business in the world after the drug business (Balode, 2019). Although much is said about this problem, there is a little information in the society. Most often, an article is published in the mass media about a solved case, which is usually solved within the framework of cooperation and causes a temporary concern in the society.

Within the framework of Schengen cooperation, the common problems must be discussed and specific opportunities for cooperation must be sought, which could close the gaps in the fight against human trafficking. According to the experts, to fight human trafficking in the Schengen area, an effective and professional system for controlling the flow of migration by carrying out checks at the external borders and preventing illegal migration must be implemented (Tentere, 2007). Bulgaria, Romania, and Ukraine are mentioned as the largest origin countries of the victims for the human trafficking (Cilvēktirdzniecība, 2018). Indeed, Austria is an important transit country, especially for the victims from the central part of the 
Eastern Europe, while Italy and Spain are the main entry points for the nonEU victims, mainly from Albania, Brazil, China, Nigeria, and Vietnam. It is important to note that the EU victims usually use authentic documents, while the victims from outside the EU use forged ones (EUROPOL, 2016).

All the implemented and planned reforms are carried out to ensure security within the area; nevertheless it is also necessary to think about the main value - freedom of movement, so the citizens of the Schengen Member States can use it. The reforms are needed and they are happening, and there will certainly be more of them in the future. The authors believe that they will be related to the use of biometric data, as the studies are already being carried out on how the use of these technologies would affect the border control at the external borders. Indeed, the reforms must be based on the strict legislation so that the Member States cannot interpret the rules according to their needs and technical capabilities, without losing sight of the human rights and the data protection.

Indeed, the reforms and other implemented measures are evaluated from the different points of view, the information presented in the mass media is not always accurate, and therefore it causes problems. Further research is needed to assess the relevance of the future reforms to the current situation and the future challenges.

\section{Conclusions and suggestions}

The authors conclude:

1. The benefit of free movement provided by the Schengen common area is the freedom felt by any traveller entering the Schengen area. The countries have worked together to create an area of free movement and, working together, have helped to make the people's travel freer and easier, while making the single area with internal and external borders more secure. Therefore, the preservation of the right of free movement is the highest value in the Schengen area.

2. To strengthen the Schengen area, the measures have been implemented both within the area and at the external borders. The EU has responded and taken a number of measures to address the security risks posed by the lack of border controls within the Schengen area.

3. In the established information systems, data is duplicated and checks in different information systems are very time consuming. The use of any information system will expose the Member States' officials to incomplete data as well as technical and practical failures. Access to the information systems and their technical support are the biggest challenges for all Member States. As well, both geographical location 
and technical capabilities prevent the full use of available information systems.

4. The reforms implemented and planned are the European Union's response to the existing challenges:

- preventing terrorism: changes to the Schengen Borders Code, the Schengen Information System (SIS), and the establishment of the ETIAS;

- responding to migration: in the future - EES as well as ETIAS; the current solution - strengthening the European Border and Coast Guard and deploying experts both at the EU external borders and in the third countries.

5. The major challenges facing the Schengen area are illegal migration, terrorism, and human trafficking, which are developing as a result of free movement and insufficient protection of the external borders, however, the countries' interests depend mainly on their geographical location and, partially, their political position.

6. Overcoming any challenge requires joint work, and, above all, this means cooperation at the various levels and between the competent authorities, without losing sight of the usefulness of the community in implementing these measures. The European Commission also emphasises the importance of this mutual cooperation.

7. In the future, the reforms related to the use of biometric data will definitely be implemented in the Schengen area.

The authors' proposals:

1. The following is required for the improvement of the Schengen evaluation system:

- to improve and strengthen the conditions of the countries' responsibility to ensure that the recommendations of the Schengen evaluation are implemented and that the shortcomings identified are fixed;

- to increase the frequency of unscheduled/unannounced Schengen evaluation visits in order to make the evaluation more objective and in line with the current situation in the Member States;

- the Member States need to be evaluated every three years, as significant changes in legislation at the EU level usually take place within five years, and the adjustment practices at the national level are not always implemented quickly and effectively enough.

2. The European Border and Coast Guard needs to set up a Permanent Corps sooner. This will benefit the Member States, as they will be able to use the rapid reaction force if necessary and to receive the necessary assistance to carry out border controls or combat cross-border crime. The Permanent Corps will consist of highly qualified border guards and, 
if necessary, this staff will be available to the Member States that would otherwise be difficult to organise on their own.

3. At the EU level, it is necessary to create a single data storage - a repository, which, when accessed from a specific information system, allows the user to see all the data that this system allows to be viewed. All information about a person, vehicle, property and other necessary information would be stored in the common data repository. Thus, when making changes, they would be made in the specific system and the user would receive the most up-to-date information during the data search and other institutions would not be burdened with data requests.

4. In order to improve cooperation and exchange of information in the Schengen area, the following must be implemented:

- joint training for the competent authorities of the Member States through practical training using information acquired during operational work;

- to involve the community in joint training by inviting them to report observations that are in line with the information disseminated in the media.

\section{References}

1. AKKERMAN, M. (2019.,nov.). THE BUSINESS OF BUILDING WALL. Retrieved January 1, 2020, from https://www.tni.org/files/publication-downloads/buildingwallsexecutive-summary-web.pdf

2. BALODE, L. (2019.,04.apr.).

Cilvēktirdzniecïba var skartjebkuru. Riskijāvērtē kritiski. Retrieved November 22, 2019, from https://lvportals.lv/norises/303203-cilvektirdznieciba-var-skart-jebkururiski-javerte-kritiski-2019

3. Cilvēktirdzniecība. (2018.,7.sept.). Baltijas jūras valstu padome uzsāk jaunu projektu cilvēku tirdzniecības novēršanai - visas Baltijas jūras reǵionu dalībvalstis iesaistījušās cīña pret šo pārrobežu noziegumu. Retrieved December 22, 2019, from http://www.cilvektirdznieciba.lv/lv/baltijas-juras-valstu-padome-uzsak-jaunuprojektu-cilveku-tirdzniecibas-noversanai---visas-baltijas-juras-regionadalibvalstis-iesaistijusas-cina-pret-so-parrobezu-noziegumtu/199

4. Eiropas Komisija. (2010.,16.nov.). Celsošana bez robežăm: Komisija ierosina stingrāk uzraudzīt, kā tiek ievēroti Šengenas noteikumi. Retrieved October 16, 2019, from https://ec.europa.eu/commission/presscorner/detail/lv/IP_10_1493

5. Eiropas Komisija. (2019.,24.jul.) Komisijas Pazinojums Eiropas Parlamentam, Eiropadomei un Padomei. Retrieved December 20, 2020, from http://publications.europa.eu/resource/cellar/af294add-aeea-11e99d01 01aa75ed71a1.0018.03/DOC_1

6. Eiropas Savienības Padome. (2017., 19.jūn.). Padomes secinājumi par ES ārējo darbību terorisma apkarošanā. Retrieved November 22, 2019, from http://data.consilium.europa.eu/doc/document/ST-10384-2017-INIT/lv/pdf 
7. Eiropas Parlamenta Birojs Latvijā. (2019.,25.okt.). Eiropas robežas klūs drošākas. Retrieved November 27, 2019, from https://www.europarl.europa.eu/latvia/lv/epl-mumi/2017/oktobra_jaunumi/entryexitsystem.html

8. European Commission. (2019.,23.okt.). Schengen accession: Croatia on the way to join the Schengen Area. Retrieved November 17, 2019, from https://ec.europa.eu/home-affairs/news/20191022_schengen-accession-croatiaway-join-area_en

9. $\quad$ EUROPOL. (2016.). Situation Report Trafficking human beings in EU. Retrieved December 22, 2019, from https://ec.europa.eu/anti trafficking/sites/antitrafficking/files/situational_report_t rafficking_in_human_beings-_europol.pdf

10. GELPERS, T. (2019., janv.). Eiropas Savienības nākotne: nākamie 15. Latvijas intereses Eiropas Savienībā, 1, 157.-162.lpp

11. KRISTOVSKIS, G. (2008). Latvia un Eiropas drošības un aizsardzības politika. Ž.Ozoliṇa, I. Ulnicāne-Ozolina. Latvija 2020. Nākotnes izaicinājumi sabiedrībai un valstij. Rīga: LU Akadēmiskais apgāds, 173.-188.lpp.

12. LIPSNIS, J. (2015.,11. nov.). Šengena - Eiropas brīvības un kopības simbols. Kurzemnieks.

13. LORENCS, J. (2018.,5.janv.). Neuzdrošinos prognozēt nākotni. Sarunas ar grāmatas "Terorisma krustugunīs. Islāma valsts" autoru Māri Kūli. Retrieved December 20, 2019, from https://www.la.lv/neuzdrosinos-prognozet-nakotni,

14. Par Eiropas Robežu un krasta apsardzi un ar ko atcel Regulas (ES) Nr.1052/2013 un (ES) 2016/1624. Eiropas Parlamenta un Padomes Regula (ES) Nr.2019/1896. Retrieved November 13, 2019, from https://eur-lex.europa.eu/legalcontent/LV/TXT/?uri=CELEX:32019R1896

15. Par Eiropas Robežu un krasta apsardzi un ar ko groza Eiropas Parlamenta un Padomes Regulu (ES) 2016/399 un ar ko atcel Eiropas Parlamenta un Padomes Regulu (EK) Nr. 863/2007, Padomes Regulu (EK) Nr. 2007/2004 un Padomes Lēmumu 2005/267/EK.(2016.,14.sept.). Eiropas Parlamenta un Padomes Regula (ES) 2016/1624. Retrieved November 22, 2019, from https://eurlex.europa.eu/legal content/LV/TXT/?uri=CELEX:32016R1624

16. RUIZ, A. (2018.,sep.). Building Walls. Retrieved January 1, 2020, from https://www.tni.org/files/publication downloads/building_walls_-_full_report__english.pdf

17. Š́NORE, E. (2016). Migrācija un politkorektums Eiropā. Latvijas Universitātes raksti Nr.813. 20.-23.lpp.

18. ŠTIBE, R. (2019., janv.). Būt vai nebūt Eiropas Savienībai 2030. Latvijas intereses Eiropas Savienībā, 1, 152.-157.lpp.

19. ŠULCA, I. (2011).Tepat, Eiropā. Rēzeknē: "Latgales druka". 171 lpp.

20. TENTERE, G.(2007., nov.). Cilvēku tirdzniecības problēma pēc robežu atvēršanas. Latvija Eiropas Savienībā, 7, 31.-32.lpp.

21. VOINS, V. (2015.). Terorisma novēršanas un apkarošanas teorētiskās un praktiskās problèmas Latvijas Republikā un Eiropas Savienībā. Promocijas darbs. Retrieved December 20, 2019, from https://www.rsu.lv/sites/default/files/dissertations/Valdis_Voins_promocijas _darbs.pdf 